\title{
Media and group influence on Generation Y consumers' attitudes towards beauty products
}

Generation Y consumers' attitudes Influencia de los medios y grupos en las actitudes de los consumidores de la Generación Y hacia los productos de belleza

\section{媒体和群体对 Y州代消费者对美容立 吕态度的影响}

Riane Cherylise Dalziel and Natasha De Klerk

School of Management Sciences, North-West University - Vanderbijlpark Campus, Vanderbijlpark, South Africa

\begin{abstract}
Purpose - The purpose of this paper is to examine the influence of two potentially important antecedents of female Generation Y consumers' attitudes towards beauty products. In particular, the impact of the media and groups is analysed through their influence on subjective norms.
\end{abstract}

Design/methodology/approach - Structural equation modelling analysis of moment structures was used to propose and test a research model by means of data from a substantial size of female Generation $Y$ consumers.

Findings - The study's results confirm that female Generation Y consumers have a favourable attitude towards beauty products and that this attitude is influenced by their subjective norms. Furthermore, the findings suggest that group influence, which includes the opinions of friends, family and peers and media influence both predict female Generation Y consumers' favourable attitude towards beauty products via their influence on this segment's subjective norms

Practical implications - These results emphasise the strategic importance of incorporating subjective norms, together with media and group influence into beauty product marketing

(C) Riane Cherylise Dalziel and Natasha De Klerk. Published in Spanish Journal of Marketing - ESIC. Published by Emerald Publishing Limited. This article is published under the Creative Commons Attribution (CC BY 4.0) licence. Anyone may reproduce, distribute, translate and create derivative works of this article (for both commercial and non-commercial purposes), subject to full attribution to the original publication and authors. The full terms of this licence maybe seen at http:// creativecommons.org/licences/by/4.0/legalcode 
communication campaigns targeting female Generation $\mathrm{Y}$ consumers. Given that this generation is known to be prevalent users of social media and often consult online peer product reviews, such strategies should also be extended beyond traditional media platforms to include social media, particularly social media influencers and online product review platforms, thereby tapping into subjective norms and group influence.

Originality/value - This study contributes to understanding female Generation Y consumers' attitudes towards beauty products, especially the combined influence of subjective norms and media and group influence on such attitudes.

Keywords Generation Y, Beauty products, Attitudes, Media influence, Group influence, Subjective norms

Paper type Research paper

\section{Resumen}

Propósito - El propósito de este trabajo es examinar la influencia de dos antecedentes potencialmente importantes de las actitudes de las consumidoras de la Generación Y hacia los productos de belleza. En concreto, se estudia la influencia de los medios de comunicación y de los grupos a través de su influencia en las normas subjetivas.

Diseño/metodología/enfoque - Se empleó el análisis de modelos de ecuaciones estructurales de estructuras de momento para proponer y probar un modelo de investigación mediante datos de un tamaño considerable de consumidoras de la Generación Y.

Resultados - Los resultados del estudio confirman que las consumidoras de la Generación Y tienen una actitud favorable hacia los productos de belleza y que esta actitud está influenciada por sus normas subjetivas. Además, los resultados sugieren que la influencia del grupo, que incluye las opiniones de amigos, familiares y compañeros, y la influencia de los medios de comunicación predicen la actitud favorable de las consumidoras de la Generación Y hacia los productos de belleza a través de su influencia en las normas subjetivas de este segmento.

Implicaciones prácticas - Estos resultados enfatizan la importancia estratégica de incorporar las normas subjetivas, junto con la influencia de los medios de comunicación y del grupo, en las campañas de comunicación de la comercialización de productos de belleza dirigidas a las consumidoras de la Generación Y. Dado que se sabe que esta generación es la usuaria habitual de los medios sociales y suele consultar en línea las revisiones de los productos, esas estrategias también deberían ampliarse más allá de las plataformas de los medios de comunicación tradicionales para incluir los medios sociales, en particular las personas que ejercen influencia en los medios sociales, y las plataformas de revisión de productos en línea, aprovechando así las normas subjetivas y la influencia del grupo.

Originalidad/valor - Este estudio contribuye a comprender las actitudes de las consumidoras de la Generación Y respecto de los productos de belleza, especialmente la influencia combinada de las normas subjetivas y la influencia de los medios de comunicación y los grupos en esas actitudes.

Palabras clave - Palabras clave Generación Y, productos de belleza, actitudes, medios de comunicación, influencia del grupo, normas subjetivas

Tipo de artículo - Trabajo de investigación

\section{摘要}

研究目的 - 本文旨在研究两个重要的潜在因素, 对Y世代女性消费者对美容产品态度的影响。具体 来说, 是通过媒体和群体对主观规范的影响来进行分析。

研究方法 - 本研究采用结构方程模型分析力矩结构, 结合相当规模的Y世代女性消费者的数据, 提 出并检验研究模型。

研究结果 - 研究结果证实, Y世代女性消费者对美容产品持积极态度, 而且这种态度受到她们主观 规范的影响。此外, 研究结果表明, 群体影响 (包括朋友、家人和同伴的意见) 和媒体影响都能通 过对 $\mathrm{Y}$ 世代女性消费者主观规范的影响来预测她们对美容产品的好感度。 
实际意义 - 本文的研究结果强调了将主观规范和媒体、群体影响纳入针对Y世代女性消费者的美容 产品营销传播活动的战略重要性。由于Y世代是社交媒体的普遍用户, 并且经常查看其他用户评

价, 因此这种策略应该超越传统媒体平台, 将社交媒体, 特别是社交媒体网络红人和在线产品评论

平台纳入其中, 利用他们对消费者主观规范和群体的影响力。

研究价值 - 本研究有助于了解Y世代女性消费者对美容产品的态度, 特别是主观规范和媒体、群体 对这种态度的综合影响。

关键词 - Y世代, 美容产品, 态度, 媒体影响, 群体影响, 主观规范
Generation Y consumers' attitudes

\section{Introduction}

Fashion is considered an essential segment of the global economy, contributing an estimated US $\$ 3$ tn annually and accounting for $2 \%$ of the world's gross domestic product (Fashion United, 2019). Fashion encompasses a variety of consumer products, such as clothing, footwear, food, housing, music, automobiles, perfumery and cosmetics (Macchion et al., 2015). Fashion reflects a society and culture's norms through symbolic innovation, as consumers use fashion to define themselves (Solomon et al., 2006), visually portray themselves to others (Evans, 1989) and improve their self-esteem (Jan and Abdullah, 2015). Given that what society deems as fashionable is in a continually state of flux, consumers constantly need to make product choices to satisfy their ever-changing fashion-related needs and wants. This state of flux is, for the most part, due to the efforts of fashion designers, producers, marketers and retailers who constantly create new fashion trends and seek to foster the society-wide adoption of those trends (Ghigi and Sassatelli, 2018). The fashion industry comprises a significant number of players, including those involved in the design, production, distribution, marketing and retailing of fashion products (Britannica, 2019b). As part of the fashion industry, the beauty product industry represents a particularly lucrative sector (Marci, 2019), experiencing strong annual growth (Cvetkovska, 2019) and representing a significant portion of the international economy. The beauty product industry has enjoyed stable and continuous growth (Lopaciuk and Lobada, 2013). This market has remained robust even through the global economic crisis, generating approximately US\$532bn globally in consumer spending in 2017 and is forecasted to reach US\$863bn by 2024 (Zion Market Research, 2018). Possible reasons for the continued success and growth of this sector include consumers becoming increasingly aware and conscious of their appearance, beauty and general grooming (Khraim, 2011), the industry rapidly embracing new market trends, such as increased eco-friendly practices (Cvetkovska, 2019) and the need for long-lasting and time-saving beauty products, such as quick-drying nail polish (Lopaciuk and Lobada, 2013). Owing to the beauty product market's sound developments, it is essential to have an understanding of consumers' consumption regarding beauty products (Chen et al., 2011).

Consumers' beliefs, attitudes and behaviour, especially those of young consumers, are influenced by their social environment (Fernandez, 2009), which includes relevant others and individuals with whom they have close contact (Luo, 2019). Social-environmental influencing factors may include peer pressure and conformity compliance, amongst others (Giovannini et al., 2015). Typically, consumers engage in product information search behaviour prior to making a purchase decision. This information may stem from different sources, including media sources, such as print and broadcast media and the internet, as well as personal sources, such as friends, peers, family, salespeople and, sometimes and even strangers (Solomon and Rabolt, 2009). Consumers spend a notable amount of time on the internet, listening to the radio, watching television and reading newspapers and magazines (Pacheco et al., 2017), often interacting with various media sources simultaneously 
SJME

25,1

\section{4}

(Borzekowski, 2019). In 2019, the estimated time per day consumers spent engaging with media was $12 \mathrm{~h}$ in America and $10 \mathrm{~h}$ in France, Germany, Canada and the UK, respectively (Dolliver, 2019). Generally, media platforms, whether traditional or digital, are heavily reliant on advertising revenue for their very existence (Jones and Kang, 2019). Given the extent of advertising content in media, the media is likely to have a salient influence on consumers' attitudes towards a range of products and services. In addition to the influence of the media on purchase decisions, consumers are subject to reference group influence, in that they often act in accordance with the prescribed norms or standards determined by a specific relevant group (Madahi and Sukati, 2012). In a seminal study, Park and Lessig (1977) uncovered that consumers, including the youth, tend to be especially susceptible to this reference group influence when purchasing conspicuous products and services. Accordingly, a more recent study by Orús et al. (2019) found friends to be an important aspect influencing consumer decision-making, as the recommendations attained from friends tend to strengthen consumer preferences irrespective of previous experiences. Essentially, fashion consumption is bound to self-concept and social identity (McNeill and Venter, 2019). Fashion products are thus highly susceptible to such social influences as they are primarily purchased for the symbolic message they convey (Pentecost and Andrews, 2010). Therefore, it is reasonable to assume that fashion products, including beauty products, are susceptible to both media and reference group influences.

The youth, currently classified under Generation Y, includes individuals born between 1986 and 2005 (Markert, 2004), which in 2020, included individuals between the ages of 15 and 34 years. While this generation represents a vital current and future market both in terms of their size and spending power (Tilford, 2018), marketing practitioners and retailers are finding it challenging targeting this generation of the youth. These individuals have grown up in a media- and information-saturated world, making them tech-savvy, wellinformed and connected (Bevan-Dye, 2019a). They are also characterised as having great confidence, awareness and individuality than members of prior generations (Laermer and Simmons, 2007). Most importantly, Generation Y is the most empowered consumer generation to date. As heavy users of social media sites (Bevan-Dye, 2018) and online consumer product review sites, members of this generation have access to and contribute to a vast source of archived and current online peer product and service reviews (Bevan-Dye, 2019a). According to Barton et al. (2012), members of this generation are more prone to perceive an expert as being a peer with first-hand experience with products and services than someone with any professional credentials. A good example of this phenomenon is the rapid rise and growing power of the social media influencer - often an ordinary Generation $\mathrm{Y}$ individual who achieves celebrity status by doing non-paid for and, hence, credible product reviews on social media platforms (Jones and Kang, 2019). Generation Y consumers place confidence in these types of reviews as they are seen to be credible and authentic (Bevan-Dye, 2020). This coupled with their access to product and service information through both traditional and digital media makes Generation Y individuals the most informed consumers in history (Bevan-Dye, 2019a).

Concern for physical appearance is notable amongst each generation's youth segment given that this represents the bachelorhood stage of the family life cycle, characterised by self-indulgence, the need for reference group acceptance and the prominent concerns of meeting and dating (Schiffman and Kanuk, 2014). That being said, members of Generation $\mathrm{Y}$ are viewed as being even more beauty conscious than the youth of previous generations and are noted for spending a substantial amount of their disposable income on beauty products (Dhanoa and Goyal, 2018; Pudaruth et al., 2015). 
While beauty products are relevant to both male and female consumers, female consumers remain the dominant target market in the beauty product industry, enjoying more attention from both beauty retailers and marketers alike (Pudaruth et al., 2015). Beauty products are deemed important by the Generation Y female segment and they apply it regularly as they associate it with fun. They feel that it is worth spending a significant amount of money on beauty products and they will continue to use these products to enhance their physical attractiveness because it increases their confidence levels, making them feel good about themselves (Rose, 2014). Female Generation Y members are also an emerging financial force, accounting for more undergraduate and graduate degrees in comparison to their male counterparts (Blumenthal and Warren, 2011) and attaining wellpaid jobs and substantial spending power (Pudaruth et al., 2015). Not only are they important in terms of their financial strength but they are also seen as influencers and trendsetters (Weidauer, 2012), especially within their social environment and society as a whole (Leelakulthanit, 2013). According to Raman (2019), female consumers are a particularly important consumer segment to target because as caregivers, they often are tasked with purchasing products on behalf of other family members. As such, they represent not only themselves but also all the individuals for whom they purchase products. However, marketers and retailers in this industry may find it difficult to target these individuals effectively as they demand unique marketing strategies. This might be because they have been exposed to an extensive amount of marketing messages throughout their lives (Branigan and Mitsis, 2014). Furthermore, Generation Y consumers deem the opinions of their peers as highly important, making them susceptible to group influence. When shopping, females tend to prefer a social environment, where they can interact with their peers. This also suggests that females might be more susceptible to group influence, as they tend to shop with their peers. They also spend a significant amount of their leisure time searching for information before making a purchase (Shephard et al., 2016). Despite the evident importance of this segment to the beauty product industry, there is limited research concerning the factors that affect these individuals' attitudes towards beauty products. As such, it is important to establish the antecedents that influence female Generation $\mathrm{Y}$ consumers' beauty product attitudes.

In light of this, to better understand the role of media and reference groups in terms of female consumers' attitudes towards beauty products, this paper sought to determine the influence of these antecedents on female Generation Y university students' beauty product subjective norms and attitudes. Such insights will assist beauty product marketers and retailers in developing more effective marketing strategies for targeting this market segment. This study specifically focusses on university students, based on the notion that a tertiary qualification is associated with a greater future earning potential together with higher social standing, resulting in these individuals being trendsetters amongst their peers (Bevan-Dye and Akpojivi, 2016).

\section{Literature review}

\subsection{Beauty products}

The beauty industry spans across numerous beauty products also referred to as cosmetics (Archna et al., 2018). The industry comprises any product used to care for, clean and improve the human body. Consumers' use of beauty products has been longstanding, dating back 6,000 years (Khraim, 2011). Together with the functional benefits thereof, beauty products are also meant to enhance the aesthetic appeal of the users (Archna et al., 2018) and to improve general attractiveness (Sankpal et al., 2016). Considered as personal necessities (Sanidewi and Paramita, 2018), beauty products are designed for applying to the face, hair
Generation $Y$ consumers' attitudes 
and body and include products such as creams, makeup, deodorants, skin-care products, hair dyes, nail polish, perfumes, toothpaste and mouthwashes (Britannica, 2019a). Consumers apply beauty products to care for their body, to enhance the appearance and improve the aroma of the body and to protect it from environmental factors, including ageing (Ergin et al., 2005). While beauty products play an important role in enhancing an individual's inherent beauty and physical features (Sahota, 2014), they are also used to alter or conceal imperfections (Denton, 2019). Female consumers have considerable purchasing power, controlling a notable $85 \%$ of all consumer spending (Ellison, 2014) and have been dominant in the beauty product industry (Pudaruth et al., 2015). Therefore, it is important for retailers to determine what influences these consumers when it comes to beauty product purchases, including media influence and group influence.

\subsection{Media influence}

The term media represents all the communication channels through which news, entertainment, education, data or marketing communication messages are disseminated (Acar, 2018). Media involves every broadcasting and narrowcasting medium and encompasses various formats. It ranges from the more traditional formats, such as print media (books, magazines, newspapers) and broadcast media (television and radio) to video games and music, right through to new emerging media such as cell phones and several kinds of software and the internet (BusinessDictionary, 2019), which includes emails and social media (Gogoi, 2017). Notably, social media has been found to be of significant importance in establishing communication between brands and consumers (Baldus et al., 2015). Owing to the evolving media environment and technological innovations, the media environment and the role of advertising in new media consumption have changed (Nosita and Lestari, 2019), such as the increase of digital newspapers (Flavián and Gurrea, 2008). For the purpose of this paper, media is described as the medium or communication channels that beauty product businesses use to deliver a marketing communication message to their target market.

To ensure that a target audience will be reached cost-effectively, it is essential to identify which type of media is most suitable for the product being promoted. Different target markets may have different media preferences, depending on their age cohort, ethnic group, social class or stage in their family lifecycle (Hawkins and Mothersbaugh, 2013). To reach specific target markets, the message should be conveyed through the appropriate medium or channel (Solomon and Rabolt, 2009). Given the contemporary media-saturated environment, the majority of consumers are likely to be influenced to a certain extent by some sort of marketing communication (Arshad and Aslam, 2015). Exposure to marketing communication messages regarding the latest fashion trends motivates consumers to recognise a problem because of a change in their desired state (Workman and Studak, 2006), which sets off the consumer decision-making process. Media has proven to have a strong influence on emerging adults' behaviour (Craig, 2013) and is a sound source of relevant product and brand information, including beauty products (Coulter et al., 2002; Tarczydlo, 2019). Interestingly, compared to their male counterparts, female consumers have also been found to be more active users of media (Coulter et al., 2002), including social media platforms (Cooper, 2018). Therefore, the following hypothesis is proposed:

H1. Media has a significant positive influence on female Generation Y consumers' beauty product subjective norms. 


\subsection{Group influence}

A reference group, referred to as all external influences that give social cues (Belch and Belch, 2015), has a substantial effect on consumers' purchasing and consumption behaviour (Madahi and Sukati, 2012). Consumers typically gather information from reference groups prior to making purchasing decisions (Dhanoa and Goyal, 2018). Schiffman and Kanuk (2015) define reference groups as "groups that serve as frames of reference for individuals in their consumption decisions because they are perceived as credible sources". Parumasur and Roberts-Lombard (2013) concur, stating that reference groups are essential for consumers to

Generation Y consumers' attitudes

use as judgement when they develop particular values and attitudes, including consumption-related behaviour patterns. Furthermore, reference groups have an impact on the sentiment consumers foster towards specific products or brands (Schulz, 2015). Consumers may have various reference groups that influence them (Hayakawa and Venieris, 1977; Sugito et al., 2018). According to Kotler and Keller (2015), reference groups can influence the behaviour of consumers differently, such as exposing an individual to new behaviours and lifestyles, influencing attitudes and self-image, as well as instilling pressure to conform. Typically, reference groups are composed of friends, colleagues, family members and celebrities (Joubert, 2013), of which friends or peers are considered to be the influential (Barry and Wentzel, 2006). According to Barry and Wentzel (2006), friends have an influence on one another by means of observational learning.

Different factors may affect the level of influence that reference groups have on a consumer's behaviour, such as the nature of the product and the individual's confidence in the purchase situation. As such, the influence of a reference group is stronger when the use of a product is visible, such as fashion products or when the individual lacks confidence in taking personal decisions, which may be influenced by personality traits (Mothersbaugh and Hawkins, 2016). Joubert (2013) indicates that there is a correlation between a consumer's behaviour and the strength of his/her bond with a reference group. Consequently, the stronger a consumer's bond or commitment with a reference group is, the more his/her behaviour will correlate with the group members' behaviour.

Even though most consumer behaviour texts identify group influence as being an important influence in consumer decision-making processes, this influence is of particular relevance when it comes to the youth, given that young consumers are more susceptible to reference group influence (Park and Lessig, 1977), particularly young female consumers (Kokoi, 2011). The youth typically consult their peers prior to making a purchase decision (Mascarenhas and Higby, 1993), especially when it comes to conspicuous products, as is the case with beauty products. Generally, young people look to their peers for acceptance with the goal of fitting in with their social environment and to reinforce their self-confidence (Fernandez, 2009). As such, group influence, especially friends, has a significant influence on young consumers' purchase behaviour (Madahi and Sukati, 2012). In particular, Fernandes and Londhe (2015) found that women showed a susceptibility to reference group influence in their beauty products consumption decisions. As subjective norms refer to social influence, which is a function of how referent others' opinions influence a consumer (Lim and Dubinsky, 2005), the following hypothesis is posited:

H2. Reference groups have a significant positive influence on female Generation Y consumers' beauty product subjective norms.

\subsection{Beauty product attitudes and subjective norms}

Marketers and retailers continuously compete against each other to capture consumers' attention and to meet their requirements, which require effective marketing strategies 
SJME

25,1

(Sankpal et al., 2016). To develop effective marketing strategies, retailers and marketers need to understand consumers' behaviour (Solomon, 2013), which is a complex process, influenced by a number of factors (Hawkins and Mothersbaugh, 2013). Prominent factors found to influence consumer behaviour include individuals' attitude towards the behaviour and their subjective norms (Ajzen and Fishbein, 1980; Fishbein and Ajzen, 1975; Schiffman and Kanuk, 2015). Two closely-related theories used in predicting and explaining consumers' intention and subsequently their behaviour are the theory of reasoned action (TRA) and the theory of planned behaviour (TPB) (Ajzen, 2015). While both these theories assert that behavioural intention is formed by an individual's attitude and subjective norms, the TPB is an extension of the TRA and includes an additional determinant of behavioural intention, namely, the measure of perceived behavioural control. This component was added to the model to account for scenarios where individuals do not have complete control over their actions (Belleau et al., 2007). However, behaviours under volitional control, such as the purchasing of beauty products, can be effectively predicted by the TRA (Armitage and Conner, 2001). As such, the TRA will produce valid predictions as consumers' intention to purchase a product is volitional (Belleau et al., 2007). The TRA is a multi-attribute attitude model, developed by Fishbein and Ajzen (1975). This model represents a widespread integration of attitude components into a structure examining the relationship between an individual's attitude and behaviour, explicating an individual's decision to engage in a given behaviour and subsequently resulting in an expected outcome (Schiffman and Kanuk, 2015). Various studies (Ramkumar and Woo, 2017; Sin and Omar, 2020) found the TRA to be a valuable model to predict consumer's engagement with beauty products and their attitudes towards beauty products. While the TRA is limited in its prediction ability, as it only includes attitudes and beliefs in determining a consumer's behaviour (Conner and Armitage, 1998), external factors can be added to the model to obtain an improved understanding of the factors that might influence consumers (Ajzen, 1991). As such, the external factors examined in this study, namely, media influence and group influence, were added to the TRA framework for explaining consumers' attitudes towards beauty products.

Attitudes are defined as a "learned predisposition to respond to a situation in a favourable or unfavourable way" (Huang et al., 2004). They are shaped by experience and learning, which, in turn, influence behaviour (Kotler and Keller, 2015). In addition, research may also form attitudes, whereby a consumer may read and share product reviews with others based on the acquired information (Noel, 2009). According to Schiffman and Kanuk (2015), attitudes are an indication of an individual's inner feeling, signifying whether someone is happy or unhappy, likes or dislikes, agrees or disagrees with an object, such as a product and product category and brand. The measurement of consumers' attitudes is important for marketers and retailers (Nosita and Lestari, 2019) because it is a determining factor in understanding consumer behaviour, as it is considered to be highly correlated with intentions to act, which, in turn, is a noteworthy predictor of behaviour (Ajzen and Fishbein, 1980). A consumer with a more favourable attitude regarding behaviour will have a stronger intention to perform the behaviour under consideration (Ajzen, 1991). Generally, consumers' attitudes are consistent but may change over time, depending on various exogenous factors, such as motivation, demographics, reference groups, product experience and technological progress (Bahtar and Muda, 2016). However, changing attitudes can be challenging due to their enduring and emotional nature (Kotler and Keller, 2015). Consequently, these predispositions cannot be swayed easily because a change in one basic attitude may require intricate changes in various others (Kotler and Armstrong, 2012). In an attempt to ensure that consumers hold positive attitudes towards a product or brand, marketers and retailers need to design and implement effective marketing strategies (Himansu, 2009). 
Along with attitudes, behavioural intentions are influenced by the social pressure a consumer feels to engage or not engage in the behaviour, namely, subjective norms (Maduku, 2013). According to Schiffman and Kanuk (2015), it is essential to understand the subjective norms that influence a consumer's behavioural intentions. Subjective norms are deemed important in the consumer behaviour field, as the decisions consumers make are dependent on the response they expect to get after performing an activity (Raman, 2019). Subjective norms are an individual's perception of other people's attitudes who are important to them, such as family, friends, colleagues and peers, towards a specific behaviour (Greaves et al., 2013). Ajzen (1991) describes it as the social pressure an individual perceives, with regard to performing or not performing a certain behaviour. This pressure is determined by an individual's normative beliefs concerning others' expectations (Kim et al., 2013) and has a significant influence on attitudes (Schepers and Wetzels, 2007). Notably, even though this relationship is not depicted in the original TRA, subjective norms also have an influence on attitudes (Schepers and Wetzels, 2007; Tarkiainen and Sundqvist, 2005). In today's society, subjective norms, also known as social norms, are formed through the opinions of friends, family members or people in similar social groups, as well as various influences on social media (Belanche et al., 2019a; Synodinos et al., 2017). Soh et al. (2017) concur that consumers usually ask around for reviews and experiences from other consumers who have already purchased and used the product before making a purchasing decision. These perceived social norms will determine an individual's belief about actions and behaviours, perceiving it as either acceptable or unacceptable (Teo et al., 2012). Consequently, the following hypothesis is posited:

H3. Subjective norms have a significant positive influence on female Generation Y consumers' attitudes towards beauty products.

\section{Research methodology}

A descriptive research design, using a single cross-sectional sampling approach was applied in this study.

\subsection{Sample and sampling method}

This study was focussed on the Generation Y female student segment and, therefore, the target population used for the empirical part of this study was specified as female Generation Y students aged between 18 and 24, enrolled at public higher education institutions (HEIs) within South Africa. As listed by Higher Education South Africa (2019), the 26 registered public HEIs in South Africa were used as the sampling frame for this study. These 26 HEIs were narrowed down to three HEI campuses within the Gauteng Province by means of judgement sampling. Using a non-probability convenience sampling method, 780 full-time female Generation Y students (260 per institution) were selected as the sample.

\subsection{Measurement instrument}

A self-administered survey questionnaire comprising structured questions was used to gather the necessary data. This questionnaire gathered data pertaining to the participants' demographic information, media influence (five items), group influence (four items), subjective norms (four items) and attitudes towards beauty products (four items). These questions were adapted from existing scales by Kim and Karpova (2010), Mascarenhas and Higby (1993), Moschis (1976) and Song et al. (2014). The media influence factor has five 
SJME

25,1

observed variables, namely, "I mostly buy those beauty products/brands that are advertised on TV, radio and magazines", "Radio, TV and magazine advertisements determine my brand loyalties", "I continue buying the same brands as long as my favourite celebrity endorses them", "I usually consult the media to determine the best buys" and "I usually look at the beauty advertisements before I buy". The group influence factor includes four observed variables, namely, "I often decide to buy those beauty products that friends have told me about", "I place a lot of confidence in friends' opinions when buying beauty products", "I often decide to buy those beauty products that I see my friends using" and "Many beauty products I own are similar to those of my friends". The subjective norms factor comprises four observed variables, namely, "People who influence my behaviour would approve of me buying beauty products", "People who are important in my life would approve of me buying beauty products", "People who influence my behaviour would encourage me to buy beauty products" and "People who are important in my life would encourage me to buy beauty products". The attitudes towards beauty products factor includes four observed variables, namely, "I think using beauty products is a good thing to do", "Using beauty products is valuable to me", "Using beauty products is beneficial to me" and "I think using beauty products is a necessary thing to do". Scaled items were measured using a six-point Likert scale, ranging from strongly disagree (1) to strongly agree (6). To explain the purpose of the study and confirm the confidentiality of the data gathered, the questionnaire included a cover letter.

\subsection{Data collection}

After receiving ethical clearance, lecturers at the three HEI campuses chosen for this study were contacted to request permission for the distribution of the questionnaires. Once permission was granted, questionnaires were distributed for voluntary completion. Participants were ensured about the confidentiality of their information and that data would only be used for statistical analysis.

\subsection{Data analysis}

IBM's Statistical Package for Social Sciences, version 25 and Analysis of Moment Structures (AMOS) were used to analyse the data obtained from the distributed questionnaires. The data set was analysed using various statistical methods, such as frequencies, percentages, collinearity diagnostics and confirmatory factor analysis using the maximum likelihood method, internal-consistency and composite reliability (CR) analysis, construct validity analysis, path analysis and descriptive statistics.

Frequencies and percentages were computed to produce a detailed profile of the sample participants. Bartlett's test of sphericity and the Kaiser-Meyer-Olkin (KMO) measure of sampling adequacy were computed to measure the factorability of the data set. A statistically significant Bartlett's test of sphericity and a KMO above 0.60 signifies that the data set is suitable for factor analysis (Field, 2009).

Nomological validity was established with the construction of a matrix of Pearson's product-moment correlation coefficients. Statistically significant relationships, in the correct direction between pairs of latent factors planned for inclusion in a model, are indicative of nomological validity. Collinearity diagnostics were conducted to establish whether any multi-collinearity concerns were present. Any tolerance values less than 0.10 and an average variance inflation factor (VIF) above 10 might suggest that there are multi-collinearity issues (Pallant, 2016).

Structural equation modelling was conducted, using AMOS, to specify a measurement model for confirmatory factor analysis purposes. The reliability of the measurement model 
was assessed by making use of Cronbach's alpha $(\alpha)$ and CR. Values above 0.70 are indicative of acceptable reliability (Malhotra, 2010). The convergent validity of the measurement model was measured by determining whether the computed latent factor loading estimates and average variance extracted (AVE) values were equal to or above the cut-off level of 0.50 . Furthermore, discriminant validity was established by computing the square root of the AVE ( $\sqrt{ }$ AVE) values, where values exceeding the correlation estimates between the relevant latent factors are indicative of discriminant validity (Hair et al., 2014). Given that the chi-square fit index is infamous for being susceptible to sample size, Byrne (2010) suggests that other fit indices be applied. With this in mind, this study used the fit indices of the root mean square error of approximation (RMSEA), the standardised root mean square residual (SRMR), the goodness-of-fit index (GFI), the incremental fit index (IFI) and the Tucker-Lewis index (TLI). Values below 0.08 for the SRMR and RMSEA, together with values of 0.90 and above for the GFI, IFI and TLI indicate an acceptable model fit (Malhotra, 2010). Path analysis was then conducted to determine the influence of media and group influence on female Generation Y students' attitudes towards beauty products, via its influence on subjective norms. The level of statistical significance was set at $p \leq 0.01$.

\section{Results}

The questionnaire produced a $78 \%$ response rate, as 610 of 780 returned questionnaires were usable. The sample comprised participants from all nine provinces of the country, all of the specified age groups and all 11 official South African languages. Most of the sample were 20 years of age $(18.7 \%)$, followed by those who were 21 years of age $(18.2 \%), 19$ years of age $(18 \%)$ and those 18 years of age $(16.6 \%)$. The majority of the participants' province of origin was indicated as the Gauteng Province $(61.3 \%)$ and Sesotho as their mother-tongue language (23.8\%). The dispersion of the sample between the three institutions was quite even, with $35.1 \%$ of the participants being enrolled at a traditional university, $32.8 \%$ at a comprehensive university and the remaining $32.1 \%$ at a university of technology. Table 1 presents a detailed profile of the participants.

Descriptive statistical analysis was then run by computing the latent factor means together with their standard deviations. In addition, Pearson's product-moment correlation

\begin{tabular}{|c|c|c|c|c|c|c|c|}
\hline Age & $n(\%)$ & Language & $n(\%)$ & $\begin{array}{l}\text { Province } \\
\text { of origin }\end{array}$ & $n(\%)$ & Institution & $n(\%)$ \\
\hline 18 & 101 (16.6) & Afrikaans & $19(3.1)$ & Eastern Cape & $18(3)$ & \multirow{4}{*}{$\begin{array}{l}\text { Comprehensive } \\
\text { university } \\
\text { Traditional } \\
\text { university }\end{array}$} & \multirow[t]{2}{*}{$200(32.8$} \\
\hline 19 & $110(18)$ & English & $41(6.7)$ & Free State & $46(7.5)$ & & \\
\hline 20 & 114 (18.7) & IsiNdebele & $8(1.3)$ & Gauteng & 374 (61.3) & & \multirow[t]{2}{*}{$214(35.1)$} \\
\hline 21 & 111 (18.2) & IsiXhosa & $50(8.2)$ & $\begin{array}{l}\text { KwaZulu- } \\
\text { Natal }\end{array}$ & $15(2.5)$ & & \\
\hline 22 & 85 (13.9) & IsiZulu & $116(19)$ & Limpopo & 77 (12.6) & \multirow[t]{9}{*}{$\begin{array}{l}\text { University of } \\
\text { technology }\end{array}$} & \multirow[t]{9}{*}{$196(32.1)$} \\
\hline 23 & $59(9.7)$ & Sepedi & 71 (11.6) & Mpumalanga & $35(5.7)$ & & \\
\hline \multirow[t]{7}{*}{24} & $30(4.9)$ & Sesotho & 145 (23.8) & Northern Cape & $2(0.3)$ & & \\
\hline & & Setswana & 73 (12) & North West & $37(6.1)$ & & \\
\hline & & SiSwati & $26(4.3)$ & Western Cape & $3(0.5)$ & & \\
\hline & & Venda & $23(3.8)$ & Missing & $3(0.5)$ & & \\
\hline & & Tsonga & $36(5.9)$ & & & & \\
\hline & & Other & $1(0.2)$ & & & & \\
\hline & & Missing & $1(0.2)$ & & & & \\
\hline
\end{tabular}

Generation Y consumers' attitudes 
SJME

25,1

122

coefficients were computed for each of the pairs of constructs. Included in this analysis, collinearity diagnostics were computed to determine whether there were any multicollinearity problems worth noting prior to running the measurement model. Correlation analysis was done to evaluate nomological validity. The means, standard deviations, correlation coefficients and collinearity statistics are illustrated in Table 2.

Given six-point Likert scale that ranged from "strongly disagree" (1) to "strongly agree" (6) used in this study, the means delineated in Table 3 show that the participants, female Generation Y students, have a favourable attitude towards beauty products and that their relevant others approve of them using beauty products. Furthermore, the results suggest that they consider the opinions of people they deem important, such as friends, family, colleagues and peers when purchasing beauty products, as well as the information on

\begin{tabular}{lccccccc}
\hline & & & & & \multicolumn{2}{c}{$\begin{array}{c}\text { Collinearity } \\
\text { statistics }\end{array}$} \\
Constructs & Mean & SD & $\begin{array}{c}\text { Media } \\
\text { influence }\end{array}$ & $\begin{array}{c}\text { Group } \\
\text { influence }\end{array}$ & $\begin{array}{c}\text { Subjective } \\
\text { norms }\end{array}$ & $\begin{array}{c}\text { Tolerance } \\
\text { VIF }\end{array}$ \\
\hline Media influence & 3.34 & 1.12 & & & & 0.839 & 1.192 \\
Group influence & 3.33 & 1.24 & $0.333^{*}$ & & & 0.857 & 1.167 \\
Subjective norms & 3.83 & 1.24 & $0.314^{*}$ & $0.282^{*}$ & & 0.865 & 1.156 \\
Attitudes & 4.32 & 1.08 & $0.186^{*}$ & $0.143^{*}$ & $0.511^{*}$ & 0.739 & 1.353 \\
Note: $*$ Significant at $p \leq 0.01$ & & & & & & \\
\end{tabular}

Table 2.

Descriptive statistics and correlation coefficients

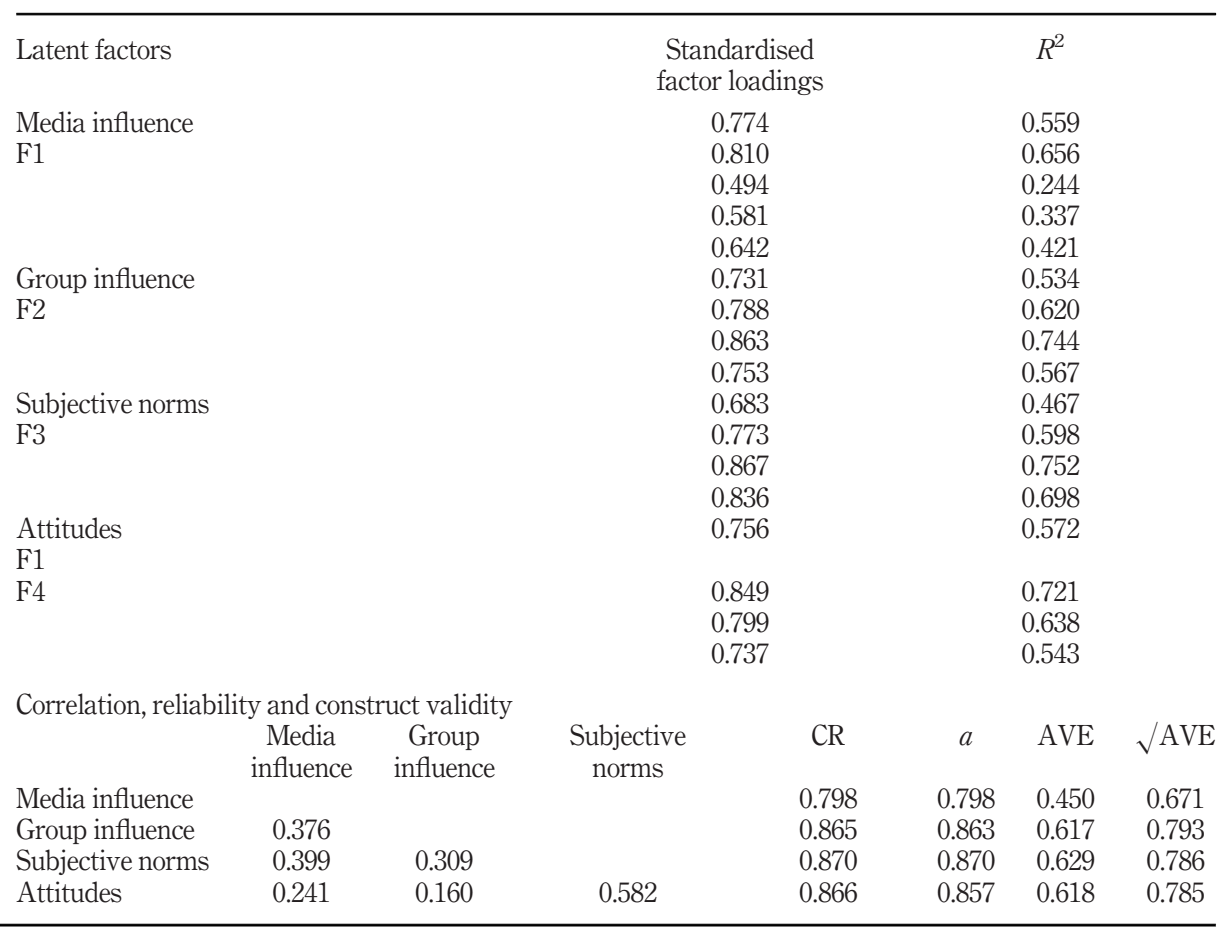

Table 3.

Measurement model estimates 
beauty products provided in the media. The computed correlation coefficients presented in Table 2 indicate that statistically significant $(\phi \leq 0.01)$ and positive relationships between each of the pairs of constructs were found, suggesting nomological validity (Hair et al., 2014). In addition, with correlation coefficients not exceeding the recommended cut-off level of 0.80 , together with tolerance values ranging from 0.739 to 0.865 and an average VIF of 1.217, there are no obvious multi-collinearity issues (Field, 2009).

The measurement model specified was assessed by computing the standardised loading estimates, error variance estimates, CR and AVE values. The following table reports on these values.

As depicted in Table 3, the Cronbach $\alpha$ values computed were all above the recommended level of 0.70 (Pallant, 2016), with 0.798 for media influence, 0.857 for attitude, 0.863 for group influence and 0.870 for subjective norms. As indicated in Table 3, all CR values exceeded 0.70 , demonstrating CR (Malhotra, 2010). The factor loadings and AVE values of group influence, subjective norms and attitude are larger than 0.50 providing evidence of convergent validity (Malhotra, 2010). Although the AVE value of 0.45 for media influence is below 0.50, the Cronbach and $\mathrm{CR}$ values suggest convergent validity. In addition, an average inter-item correlation value of 0.441 , which is between 0.15 and 0.5 , is indicative of convergent validity (Clark and Watson, 1995), as well as corrected item-to-total values above 0.3 (Pallant, 2016). Discriminant validity was established, in line with Hair et al. (2014), by comparing the $\sqrt{ }$ AVE values with the correlation coefficients. The $\sqrt{ }$ AVE values for each factor exceeded the correlation coefficients, due to sharing more variance with its measures than the variance it shared with the other factors in the model, thereby suggesting discriminant validity. As such, the scale used in this study is deemed reliable and valid. A significant chi-square value of 384.152 with 113 degrees of freedom (df) was computed. However, this method of testing model fit is subject to large sample sizes and therefore alternative model fit indices were inspected. These alternative fit indices included the GFI, IFI, the TLI, the SRMR and the RMSEA. All of these computed fit indices suggested good model fit, with an SRMR value of 0.0406 , an RMSEA value of 0.063 , a GFI of 0.93 , an IFI of 0.945 and a TLI of 0.934 .

In accordance with the measurement model, a structural model was then specified to test the proposed hypotheses. That is, whether media and group influence have a significant positive indirect influence on the female portion of Generation Y students' beauty product attitudes through their influence on subjective norms. These results are presented in Table 4.

The results in Table 4 indicate that media influence $(\beta=0.331, p \leq 0.01)$ and group influence $(\beta=0.182, p \leq 0.01)$ have a positive significant impact on subjective norms. Similarly, subjective norms $(\beta=0.582, p \leq 0.01)$ have a significant positive influence on attitude. Therefore, all three proposed hypotheses are supported. In Figure 1, the regression path estimates are graphically illustrated.

The findings depicted in both Table 4 and Figure 1 are in line with a number of previous studies (López-Nicolás et al., 2008; Mangleburg et al., 2004; Schepers and Wetzels, 2007; Shi and Xie, 2013). While the structural model again returned a significant chi-square value of 384.530 , the

\begin{tabular}{lccc}
\hline Hypotheses & Estimates & $p$-values & Results \\
\hline H1 Media influence $\rightarrow$ Subjective norms & 0.331 & 0.000 & Significant \\
H2 Group influence $\rightarrow$ Subjective norms & 0.182 & 0.000 & Significant \\
H3 Subjective norms $\rightarrow$ Attitudes & 0.582 & 0.000 & Significant
\end{tabular}

Note: Significant at $p \leq 0.01$

\section{Generation Y consumers' attitudes}

123

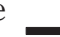


SJME

25,1

other incremental fit indices returned good model fit values. The values comprised $\mathrm{GFI}=0.930$, $\mathrm{IFI}=0.945$, TLI $=0.935, \mathrm{SRMR}=0.0408$ and RMSEA $=0.062$. The squared multiple correlation coefficient for subjective norms is 0.19 , concluding that media and group influence collectively explain $19 \%$ of the variance in female Generation Y students' subjective norms towards beauty products. Furthermore, the squared multiple correlation coefficient for attitude is 0.34 , demonstrating that subjective norms explain $34 \%$ of the variance in the female portion of Generation Y students' attitudes towards beauty products. The indirect effect that media influence exerts on female Generation Y students' attitude is equal to $13 \%$, whereas the indirect effect that group influence has on attitude equates to $8 \%$. The variance explained might be as a result of the possibility that other factors might contribute to explaining female Generation $\mathrm{Y}$ students' beauty product attitudes.

\section{Discussion and implications}

This study contributes to the literature by applying the TRA approach to explaining consumers' attitudes towards beauty products. The study empirically determined the antecedents that contribute to consumers' favourable attitudes towards beauty products, with specific reference to female Generation Y consumers. The TRA model (Fishbein and Ajzen, 1975) was extended to include media influence and group influence as predictors of female Generation Y consumers' attitudes towards beauty products. The findings of this study indicate that female Generation $\mathrm{Y}$ consumers have a favourable attitude towards beauty products and are influenced by subjective norms. Furthermore, the findings suggest that media and group influence, such as friends, both have a significant impact on their favourable attitudes towards beauty products via their influence on this segment's subjective norms.

Based on the evidence in the sample, the results suggest that Generation Y consumers view beauty products as valuable, beneficial and important. Furthermore, evidence from the sample suggests that they value the approval, opinions and reassurance of friends and other relevant other's opinions, as well as probe the media when purchasing beauty products. The implications of these findings are in line with what is specified in the literature and emphasise the strategic importance of marketers incorporating subjective norms, together with media and group influence into beauty product marketing communication campaigns targeting female Generation Y consumers.

The insights gained from this study may assist researchers, marketers, retailers and social influencers in understanding those predictors of Generation Y female consumers' beauty product attitudes. In line with what is specified in the literature, it is evident that this

Figure 1.

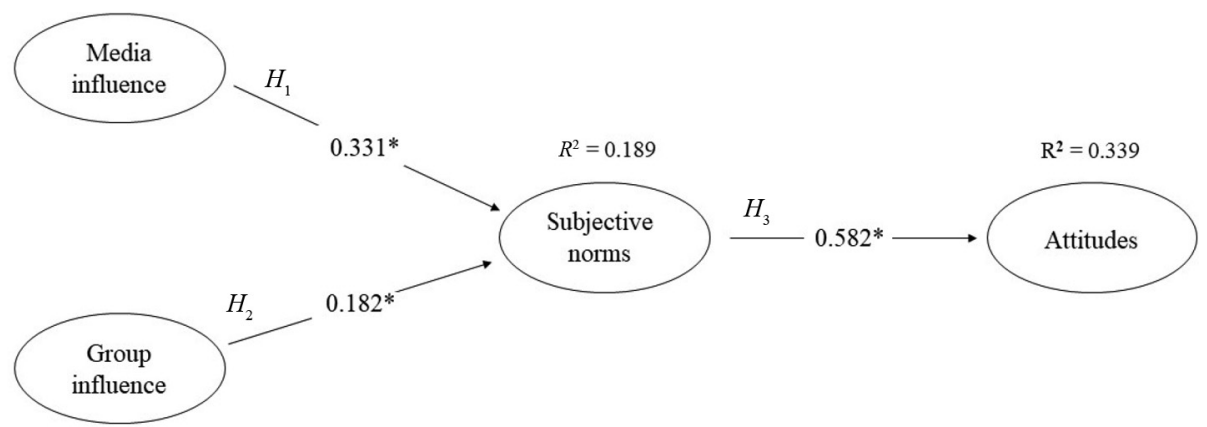

Note: *Significant at $p \leq 0.01$ 
generational segment is avid users of various media sources, including traditional and social media. The implications of these findings for marketers is to ensure that marketing campaigns should be focussed on incorporating a vast array of these media sources when advertising beauty products to Generation Y consumers; especially the female portion of this generational segment, as they tend to search for information to a greater extent when deciding to purchase a product (Shephard et al., 2016) and being the dominant gender with regard to beauty products (Pudaruth et al., 2015). Owing to this generation's use of various media sources, marketers should extend their marketing communication strategies beyond traditional media platforms, such as television, radio and magazines, to include social media, particularly media influencers, celebrity endorsers and online product review platforms, thereby tapping into subjective norms and group influence.

Given that Generation Y consumers use the internet and social media networks on a regular basis (Moreno et al., 2017), these consumers should be provided with a user-friendly digital platform to express their satisfaction with products, services and brands. Such platforms can include Instagram and Facebook, as these platforms are popular amongst younger generations (Bevan-Dye, 2019b; Casaló et al., 2017a). According to Belanche et al. (2019b), Instagram stories are an effective marketing medium to use when targeting Generation Y. With Instagram having increased in adoption amongst both consumers and brands (Casaló et al., 2017b) and Facebook boasting with 2.32 billion active monthly users at the end of 2018 (Bevan-Dye, 2019b), these two platforms should be considered by marketing practitioners and retailers. By making use of such platforms, both media and group influence are used in marketing products and services to current and potential consumers. Furthermore, the focus of beauty product advertising copy should be on the various groups salient to the Generation Y female cohort, to enhance the subjective norms of using beauty products. Given the role that media play in the consumer-decision-making process prior to purchasing, whereby consumers, especially Generation Y consumers, use social networking sites for social validation and self-representation, marketers are encouraged to monitor product reviews on third-party websites and incorporate a space on their company website for consumers to do product reviews. Marketers should further provide consumers with an electronic platform, such as a chat room, to engage with their peers by sharing information and stories and make recommendations, as well as engaging with social influencers. These marketing efforts will enhance the social visibility and acceptability of beauty products amongst this generation.

\section{Limitations and suggestions for future research}

Caution should be exercised when interpreting the results, as this study has several limitations. The most important limitation is that a non-probability convenience sample was selected from the sampling frame, making the generalising of the results potentially problematic. Although the sample provides evidence of being representative of the population, comprising participants from all the nine provinces within South Africa, this study was country- and province-specific, focussing on students enrolled at universities in one province only. There is a possibility that beauty product attitudes of students enrolled at universities outside this province or the South African market may be influenced by other factors than group and media influence. Another limitation is that a cross-sectional research design was used for this study and as such only provides a snapshot in time. Therefore, a longitudinal study, comprising a larger and more geographically diverse sample and market segments, such as members of Generation X, would possibly render results that will add more value to current literature, as this might also provide insight into the possible reasons
Generation $Y$ consumers' attitudes 
SJME

25,1

why these consumers are influenced by the media and their reference groups. Information emanating from such a longitudinal study can be particularly beneficial to marketers and retailers, giving them a competitive edge in an exceptionally competitive industry. Furthermore, there is a need to investigate other factors that might have an influence on the female portion of Generation Y students' beauty product attitudes. This is evident, as the factors investigated in this study explain $34 \%$ of the variance in female Generation Y students' beauty product attitudes. This will also provide marketers and retailers within the beauty product sector with an advantage when designing marketing strategies to target Generation $\mathrm{Y}$ female consumers, as they will have more information regarding the factors influencing these consumers' attitudes towards beauty products.

\section{Conclusion}

This study strove to uncover the impact of female Generation Y consumers' attitudes towards beauty products via their influence on subjective norms. The findings confirm that female Generation Y consumers have a favourable attitude towards beauty products, which is influenced by their subjective norms. Furthermore, the findings suggest that group influence and media influence both predict this segment's subjective norms. The findings highlight the strategic importance of using subjective norms, together with media and group influence into beauty marketing communication campaigns, which extend beyond traditional media platforms, such as social media influencers and online product review platforms.

\section{References}

Acar, Y. (2018), "Media and culture rethinking culture and media", The Journal of Academic Social Sciences, Vol. 67 No. 67, pp. 597-602.

Ajzen, I. (1991), "The theory of planned behavior", Organizational Behavior and Human Decision Processes, Vol. 50 No. 2, pp. 179-211.

Ajzen, I. (2015), "The theory of planned behaviour is alive and well and not ready to retire: a commentary on sniehotta, presseau, and Araujo-Soares", Health Psychology Review, Vol. 9 No. 2, pp. 131-137.

Ajzen, I. and Fishbein, M. (1980), Understanding Attitudes and Predicting Social Behavior, Prentice-Hall, Englewood Cliffs, NJ.

Archna, P., Krithika, R. and Susshruthi, G. (2018), "A study of digital shopping behaviour of women with respect to beauty and personal care products”, in Bhakar, S.S., Kaurav, R.P.S., Angrawal, V. and Gupta, M. (Eds), Proceedings of the 10th International Conference on Digital Strategies for Organisational success, available at: https:/papers.ssrn.com/sol3/papers.cfm?abstract_id= 3307014 (accessed 20 November 2019).

Armitage, C.J. and Conner, M. (2001), "Efficacy of the theory of planned behaviour: a meta-analytic review", British Journal of Social Psychology, Vol. 40 No. 4, pp. 471-499.

Arshad, M.S. and Aslam, T. (2015), "The impact of advertisement on consumer's purchase intentions", available at: http://dx.doi.org/10.2139/ssrn.2636927 (accessed 20 November 2019).

Bahtar, A.Z. and Muda, M. (2016), "The impact of user-generated content (UGC) on product reviews towards online purchasing - a conceptual framework", Procedia Economics and Finance, Vol. 37, pp. 337-342.

Baldus, B.J., Voorhees, C. and Calantone, R. (2015), "Online brand community engagement: scale development and validation", Journal of Business Research, Vol. 68 No. 5, pp. 978-985.

Barry, C.M. and Wentzel, K.R. (2006), "Friend influence no prosocial behavior: the role of motivational factors and friendship characteristics", Developmental Psychology, Vol. 42 No. 1, pp. 153-163. 
Barton, C., Fromm, J. and Egan, C. (2012), "The millennial consumer: debunking stereotypes: the Boston consulting group", available at: www.bcgperspectives.com/content/articles/ consumer_insight_marketing_millennial_consumer/(accessed 15 November 2020).

Belanche, D., Casaló, L.V. and Flavián, C. (2019a), "Artificial intelligence in FinTech: understanding robo-advisors adoption among customers", Industrial Management and Data Systems, Vol. 119 No. 7, pp. 1411-1430.

Belanche, D., Cenjor, I. and Pérez-Rueda, A. (2019b), "Instagram stories versus Facebook wall: an advertising effectiveness analysis", Spanish Journal of Marketing - ESIC, Vol. 23 No. 1, pp. 69-94.

Belch, G.E. and Belch, M.A. (2015), Advertising and Promotion: An Integrated Marketing Communications Perspective, McGraw-Hill Education, New York, NY.

Belleau, B.D., Summers, T.A., Xu, Y. and Pinel, R. (2007), "Theory of reasoned action: purchase intention of young consumers", Clothing and Textiles Research Journal, Vol. 25 No. 3, pp. 244-257.

Bevan-Dye, A.L. (2018), "Relationship between generation Y students' link sharing motives and wordof-mouth communication on Facebook", International Journal of eBusiness and eGovernment Studies, Vol. 10 No. 1, pp. 1-17.

Bevan-Dye, A.L. (2019a), "Influence of perceived usefulness and credibility on South African generation Y students' perceived value of online consumer reviews", International Journal of Innovation, Creativity and Change, Vol. 5 No. 2, pp. 679-696.

Bevan-Dye, A.L. (2019b), "South African generation Y students' motives for using Facebook", Polish Journal of Management Studies, Vol. 19 No. 2, pp. 48-60.

Bevan-Dye, A.L. (2020), “Antecedents of generation Y consumers' usage frequency of online consumer reviews”, Spanish Journal of Marketing - ESIC, Vol. 24 No. 2, pp. 193-212.

Bevan-Dye, A.L. and Akpojivi, U. (2016), "South African generation Y students' self-disclosure on Facebook", South African Journal of Psychology, Vol. 46 No. 1, pp. 114-129.

Blumenthal, S. and Warren, K. (2011), "How healthy are today's young adults?", available at: www. huffpost.com/entry/millennial-health_n_862162 (accessed 12 November 2019).

Borzekowski, L.G. (2019), "Constancy (the new media “C”) and future generations”, Health Education and Behavior: The Official Publication of the Society for Public Health Education, Vol. 46, pp. 20-29.

Branigan, E. and Mitsis, A. (2014), "Reach for generation Y: using celebrity endorsement to communicate about nonprofit causes with young people in Australia", International Journal of Nonprofit and Voluntary Sector Marketing, Vol. 19 No. 4, pp. 314-321.

Britannica (2019a), "Cosmetic", available at: https://global.britannica.com/art/cosmetic (accessed 17 November 2019).

Britannica (2019b), "Fashion industry", available at: https://britannica.com/art/fashion-industry (accessed 20 November 2019).

BusinessDictionary (2019), "Media", available at: www.businessdictionary.com/definition/\%20media. html (accessed 12 November 2019).

Byrne, B.M. (2010), Structural Equation Modelling with AMOS: basic Concepts, Applications, and Programming, Routledge, New York, NY.

Casaló, L.V., Flavián, C. and Ibáñez-Sánchez, S. (2017a), "Antecedents of consumer intention to follow and recommend an Instagram account", Online Information Review, Vol. 41 No. 7.

Casaló, L.V., Flavián, C. and Ibáñez-Sánchez, S. (2017b), "Understanding consumer interaction on Instagram: the role of satisfaction, hedonism, and content characteristics", Cyberpsychology, Behavior, and Social Networking, Vol. 20 No. 6, pp. 369-375.

Chen, C.W., Chen, T.H. and Lin, Y.F. (2011), "Statistical analysis for consumers' intentions of purchasing cosmetics", African Journal of Business Management, Vol. 5 No. 29, pp. 11630-11635.

\section{Generation Y consumers' attitudes}


Clark, L.A. and Watson, D. (1995), "Constructing validity: basic issues in objective scale development", Psychological Assessment, Vol. 7 No. 3, pp. 309-319.

Cooper, P. (2018), "Social media advertising stats that matter to marketers in 2018", available at: https:// blog.hootsuit.com/social-media-advertising-stats/ (accessed 20 November 2019).

Conner, M. and Armitage, C.A. (1998), "Extending the theory of planned behavior: a review and avenues for further research", Journal of Applied Social Psychology, Vol. 28 No. 15, pp. 1429-1464.

Coulter, R.A., Feick, L.F. and Price, L.L. (2002), "Changing faces: cosmetics opinion leadership among women in the new Hungary", European Journal of Marketing, Vol. 36 Nos 11/12, pp. $1287-1308$.

Craig, C.M. (2013), "Socialization of product placements: how are emerging adults influenced by parents, peers, and media?", (Doctoral thesis), Texas Tech University Lubbock, Tex.

Cvetkovska, L. (2019), "24 Beauty industry statistics that will impress you", available at: https:// loudcloudhealth.com/beauty-industry-statistics/ (accessed 13 November 2019).

Denton, K. (2019), "How social media uses the psychology of persuasion to influence the purchase of beauty products to the young generations", (Honors thesis): Southern New Hampshire University Manchester, $\mathrm{NH}$.

Dhanoa, R. and Goyal, N. (2018), "Millennial generations' susceptibility to interpersonal influence: a case of personal care products purchases", International Journal of Management Studies, Vol. 5, pp. 73-78.

Dolliver, M. (2019), “Time spent with media 2019 report”, available at: https://emarketer.com/content/ time-spent-with-media-2019 (accessed 20 November 2019).

Ellison, S. (2014), "Five guiding principles to help brands engage with women", available at: https:// theguardian.com/media-network/media-network-blog/2014/jul/11/brands-engage-female-consumers/ (accessed 15 November 2019).

Ergin, E.A., Özdemir, H. and Parılt1, N. (2005), "Brand loyalty in the cosmetics industry: a field study on turkish women's Brand loyalty among cosmetic products", Journal of Business and Economics Research, Vol. 3 No. 5, pp. 5-16.

Evans, M. (1989), “Consumer behaviour towards fashion”, European Journal of Marketing, Vol. 23 No. 7, pp. 7-16.

Fashion United (2019), "Global fashion industry statistics: international apparel", available at: https:/fashionunited.com/global-fashion-industry-statistics/\#tab2 (accessed 12 November 2019).

Fernandez, P.R. (2009), "Impact of branding on gen Y's choice of clothing", Journal of the South East Asia Research Centre for Communications and Humanities, Vol. 1 No. 1, pp. 79-95.

Fernandes, S. and Londhe, B.R. (2015), "Influence of social reference group on buying behaviour, a comparative study on working and non-working women in Bangalore - a pilot study analysis", Indian Journal of Science and Technology, Vol. 8, pp. 95-124.

Field, A. (2009), Discovering Statistics Using SPSS, SAGE Publications, London.

Fishbein, M. and Ajzen, I. (1975), Belief, Attitudes, Intention and Behavior: An Introduction to Theory and Research, Addison-Wesley, Philippines.

Flavián, C. and Gurrea, R. (2008), "Reading newspapers on the internet: the influence of websites 'attributes”, Internet Research, Vol. 18 No. 1, pp. 26-45.

Ghigi, R. and Sassatelli, R. (2018), "Body projects: fashion, aesthetic modifications and stylized selves", in Kravets, O., Maclaran, P, Miles, S. and Venkatesh, A. (Eds), The SAGE Handbook of Consumer Culture, SAGE Publications, London, pp. 290-550.

Giovannini, S., Xu, Y. and Thomas, J. (2015), "Luxury fashion consumption and generation Y consumers", Journal of Fashion Marketing and Management: An International Journal, Vol. 19 No. 1, pp. 22-40. 
Gogoi, S. (2017), "Communicators need to innovate to stay relevant in an evolving media landscape", available at: https://first.partners/views/communicators-need-to-innovate-to-stay-relevant-in-anevolving-media-landscape/ (accessed 21 November 2019).

Greaves, M., Zibarras, L.D. and Stride, C. (2013), "Using the theory of planned behaviour to explore environmental behavioural intentions in the workplace", Journal of Environmental Psychology, Vol. 34 No. 1, pp. 109-120.

Hair, J.F., Black, W.C., Babin, B.J. and Anderson, R.E. (2014), Multivariate Data Analysis: A Global Perspective, Pearson Prentice-Hall, Upper Saddle River, NJ.

Hawkins, D.I. and Mothersbaugh, D.L. (2013), Consumer Behavior: building Marketing Strategy, 12th ed., McGraw-Hill, New York, NY.

Hayakawa, H. and Venieris, Y. (1977), “Consumer interdependence via reference groups”, Journal of Political Economy, Vol. 85 No. 3, pp. 599-615.

Higher Education South Africa (2019), SA Universities, available at: www.govpage.co.za/universities. $\mathrm{html}$ (accessed 15 November 2019).

Himansu, S.M. (2009), "Consumer behaviour - 4: attitude, individual determinants of behaviour", available at: www.scribd.com/doc/19769789/Consumer-Behaviour-4-Attitude (accessed 20 November 2019).

Huang, J.H., Lee, B.C. and Ho, S.H. (2004), "Consumer attitude toward gray market goods", International Marketing Review, Vol. 21 No. 6, pp. 598-614.

Jan, M.T. and Abdullah, K. (2015), "Fashion: Malaysian Muslim women perspective", European Scientific Journal, Vol. 1, pp. 438-454.

Jones, A. and Kang, J. (2019), "Media technology shifts: exploring millennial consumers' fashioninformation- seeking behaviors and motivations", Canadian Journal of Administrative Sciences/ Revue Canadienne Des Sciences de L'administration, Vol. 37 No. 1, pp. 13-29.

Joubert, P., (Ed.) (2013), Introduction to Consumer Behaviour, Juta, Cape Town, SA.

Khraim, H.S. (2011), "The influence of brand loyalty on cosmetics buying behavior of UAE female consumers", International Journal of Marketing Studies, Vol. 3 No. 2, pp. 123-133.

Kim, H. and Karpova, E. (2010), "Consumer attitudes toward fashion counterfeits: application of the theory of planned behavior", Clothing and Textiles Research Journal, Vol. 28 No. 2, pp. 79-94.

Kim, E., Ham, S., Yang, I.S. and Choi, J.G. (2013), “The roles of attitude, subjective norm, and perceived behavioral control in the formation of consumers' behavioral intentions to read menu labels in the restaurant industry", International Journal of Hospitality Management, Vol. 35, pp. 203-213.

Kokoi, I. (2011), "Female buying behaviour related to facial skin care products", (Bachelor's Thesis) University of Applied Sciences, Helsinki.

Kotler, P. and Armstrong, G. (2012), Principles of Marketing, Pearson Education, Essex.

Kotler, P. and Keller, K.L. (2015), Marketing Management, Pearson Education, Upper Saddle River.

Laermer, R. and Simmons, M. (2007), Punk Marketing: Get Off Your Ass and Join the Revolution, HarperCollins, New York.

Leelakulthanit, O. (2013), "The happiness of gen Y female and male shoppers", paper presented at the 1st International Conference on New Directions in Business, Management, Finance, and Economics, Famagusta, 12-14 September.

Lim, H. and Dubinsky, A.J. (2005), "The theory of planned behavior in e-commerce: making a case for interdependencies between salient beliefs", Psychology and Marketing, Vol. 22 No. 10, pp. 833-855.

Lopaciuk, A. and Lobada, M. (2013), "Global beauty industry trends in the 21st century", Proceedings of the Management, Knowledge and Learning International Conference, Zadar, Croatia, pp. 1079-1087. 
SJME

25,1

López-Nicolás, C., Molina-Castillo, F.J. and Bouwman, H. (2008), "An assessment of advanced mobile services acceptance: contributions from TAM and diffusion theory models", Information and Management, Vol. 45 No. 6, pp. 359-364.

Luo, S. (2019), "Consumers and their brand love relationships", (Doctoral thesis): University of Otago, New Zealand.

McNeill, L. and Venter, B. (2019), “Identity, self-concept and young women's engagement with collaborative, sustainable fashion consumption models", International Journal of Consumer Studies, Vol. 43 No. 4, pp. 368-378.

Macchion, L., Moretto, A., Caniato, F., Caridi, M., Danese, P. and Vinelli, A. (2015), "Production and supply network strategies within the fashion industry", International Journal of Production Economics, Vol. 163, pp. 173-188.

Madahi, A. and Sukati, I. (2012), "The effect of external factors on purchase intention amongst young generation in Malaysia”, International Business Research, Vol. 5 No. 8, pp. 153-159.

Maduku, D.K. (2013), "Predicting retail banking customers' attitude towards internet banking services in South Africa", Southern African Business Review, Vol. 17 No. 3, pp. 76-100.

Malhotra, N.K. (2010), Marketing Research: An Applied Orientation, Pearson Prentice-Hall, Upper Saddle River, NJ.

Mangleburg, T.F., Doney, P.M. and Bristol, T. (2004), "Shopping with friends and teens' susceptibility to peer influence", Journal of Retailing, Vol. 80 No. 2, pp. 101-116.

Marci, K. (2019), "What the \$532bn beauty industry looks like in 2019", available at: https://edited.com/ resources/what-the-beauty-industry-looks-like-in-the-future/ (accessed 14 November 2019).

Markert, J. (2004), "Demographics of age: generational and cohort confusion”, Journal of Current Issues and Research in Advertising, Vol. 26 No. 2, pp. 11-25.

Mascarenhas, O.A.J. and Higby, M.A. (1993), "Peer, parent, and media influences in teen apparel shopping", Journal of the Academy of Marketing Science, Vol. 21 No. 1, pp. 53-58.

Moreno, F.M., Lafuente, J.G., Carreon, F.A. and Moreno, S.M. (2017), "The characterization of the millennials and their buying behaviour", International Journal of Marketing Studies, Vol. 9 No. 5 , pp. 135-144.

Moschis, G.P. (1976), "Social comparison and informal group influence”, Journal of Marketing Research, Vol. 13 No. 3, pp. 237-244.

Noel, H. (2009), Consumer Behaviour, AVA Academia, Lausanne.

Nosita, F. and Lestari, T. (2019), "The influence of user generated content and purchase intention on beauty products", Journal of Management and Marketing Review, Vol. 4 No. 3, pp. 171-183.

Orús, C., Gurrea, R. and Ibáñez-Sánchez, S. (2019), "The impact of consumers' positive online recommendations on the omnichannel webrooming experience", Spanish Journal of Marketing ESIC, Vol. 23 No. 3, pp. 397-414.

Pallant, J. (2016), SPSS Survival Manual, Open University Press, London.

Pacheco, L., Da Silva, M.T., Brites, M.J., Henriques, S. and Damásio, M.J. (2017), "Patterns of european youngsters' daily use of media”, Observatorio, Vol. 1, pp. 1-18.

Park, C.W. and Lessig, V.P. (1977), "Students and housewives: differences in susceptibility to reference group influence", Journal of Consumer Research, Vol. 4 No. 2, pp. 102-110.

Parumasur, S.B. and Roberts-Lombard, M. (2013), Consumer Behaviour, Juta, Cape Town, SA.

Pentecost, R. and Andrews, L. (2010), "Fashion retailing and the bottom line: the effects of generational cohorts, gender, fashion fanship, attitudes and impulse buying on fashion expenditure", Journal of Retailing and Consumer Services, Vol. 17 No. 1, pp. 43-52.

Pudaruth, S., Juwaheer, T.D. and Seewoo, Y.D. (2015), "Gender-based differences in understanding the purchasing patterns of eco-friendly cosmetics and beauty care products in Mauritius: a study of female customers", Social Responsibility Journal, Vol. 11 No. 1, pp. 179-198. 
Raman, P. (2019), “Understanding female consumers' intention to shop online: the role of trust, convenience and customer service", Asia Pacific Journal of Marketing and Logistics, Vol. 31 No. 4, pp. 1138-1160.

Ramkumar, B. and Woo, H. (2017), "Modelling consumers' attitude and intention to use fashion and beauty subscription-based online services (SOS): a TRA approach", Proceedings of the International Textile and Apparel Association Annual Conference, St Petersburg, FL.

Rose, S. (2014), "Millennials and beauty: serving the eye of a new generation of beholders", available at: https:/informaconnect.com/millennials-and-beauty-serving-the-eye-of-a-new-generation-of-beholders/ (accessed 15 November 2019).

Sahota, A. (2014), "Greening the cosmetics industry: natural, organic and environmental", South African Pharmaceutical and Cosmetic Review, Vol. 41 No. 10, pp. 31-34.

Sanidewi, H. and Paramita, E.L. (2018), "The role of perceived green marketing and Brand equity on green purchasing decision”, Diponegoro International Journal of Business, Vol. 1 No. 1, pp. 14-25.

Sankpal, S., Dua, B., Raizada, P., Tomar, R., Sharma, B., Sharma, S., Gonuguntla, D. and Shrivastava, V. (2016), "Impact of novelty on purchase intention of beauty products: a study of face wash", in Bhakar, S.S and Mathur, G. (Eds), A Systematic Guide from Research to Manuscript, Vol. 144, Bharti Publications. New Delhi, p. 306.

Schepers, J. and Wetzels, M. (2007), "A meta-analysis of the technology acceptance model: investigating subjective norm and moderation effects", Information and Management, Vol. 44 No. 1, pp. 90-103.

Schiffman, L.G. and Kanuk, L.L. (2014), Consumer Behavior, Pearson Prentice Hall, Upper Saddle River, NJ.

Schiffman, L.G. and Kanuk, L.L. (2015), Consumer Behavior, Pearson Prentice-Hall, Upper Saddle River, NJ.

Schulz, H.M. (2015), "Reference group influence in consumer role rehearsal narratives", Qualitative Market Research: An International Journal, Vol. 18 No. 2, pp. 210-229.

Shephard, A., Pookulangara, S., Kinley, T.R. and Josiam, B.M. (2016), "Media influence, fashion, and shopping: a gender perspective", Journal of Fashion Marketing and Management, Vol. 20 No. 1, pp. 4-18.

Shi, B. and Xie, H. (2013), "Peer group influence on urban preadolescents' attitudes toward material possessions: social status benefits of material possessions", Journal of Consumer Affairs, Vol. 47 No. 1, pp. 46-71.

Sin, L.M. and Omar, B. (2020), "The impact of Korean wave on Malaysian metrosexual grooming attitude and behaviour: the moderating role of visual media consumption", Media Watch, Vol. 11 No. 2, pp. 263-280.

Soh, C.Q.Y., Rezaei, S. and Gu, M.L. (2017), "A structural model of the antecedents and consequences of generation Y luxury fashion goods purchase decisions", Young Consumers, Vol. 18 No. 2, pp. 180-204.

Solomon, M.R. (2013), Consumer Behavior: Buying, Having, and Being, Pearson Prentice-Hall, Boston, MA.

Solomon, M.R. and Rabolt, N.J. (2009), Consumer Behavior in Fashion, Pearson Prentice-Hall, Englewood Cliffs, NJ.

Solomon, M.R., Bamossy, G., Askegaad, S. and Hogg, M.K. (2006), Consumer Behavior: A European Perspective, Pearson Education, Essex.

Song, H., You, G.J., Reisinger, Y., Lee, C.K. and Lee, S.K. (2014), "Behavioral intention of visitors to an oriental medicine festival: an extended model of goal directed behavior", Tourism Management, Vol. 42, pp. 101-113.

Sugito, S., Lubis, A.N., Rini, E.S. and Absah, Y. (2018), "Influence of reference group indicators to the image of modern retail (case in Indonesia)", Junior Scientific Researcher, Vol. 4, pp. 67-79. 
SJME

25,1

Synodinos, C., Price, D.G. and Bevan-Dye, A.L. (2017), "The influence of flow, subjective norms and attitude on generation $\mathrm{Y}$ students' adoption intentions toward mobile games", International Journal of eBusiness and eGovernment Studies, Vol. 9 No. 2, pp. 72-87.

Tarczydlo, B. (2019), "Content communication in building Brand image via social media - case study", Proceedings of the 37th International Scientific Conference on Economic and Social Development, Baku, Croatia, pp. 1338-1345.

Tarkiainen, A. and Sundqvist, S. (2005), "Subjective norms, attitudes and intentions of Finnish consumers in buying organic food", British Food Journal, Vol. 107 No. 11, pp. 808-822.

Teo, A.C., Tan, G.W.H., Cheah, C.M., Ooi, K.B. and Yew, K.T. (2012), "Can the demographic and subjective norms influence the adoption of mobile banking?", International Journal of Mobile Communications, Vol. 10 No. 6, pp. 578-597.

Tilford, C. (2018), "The millennial moment - in charts", available at: www.ft.com/content/f81ac17a68ae-11e8-b6eb-4acfcfb08c11 (accessed 28 August 2020).

Weidauer, J. (2012), "Millennials determine future of retail", available at: https://drugstorenews.com/ news/millennials-determine-future-retail (accessed 24 November 2019).

Workman, J.E. and Studak, C.M. (2006), "Fashion consumers and fashion problem recognition style", International Journal of Consumer Studies, Vol. 30 No. 1, pp. 75-84.

Zion Market Research (2018), "Cosmetic products market report: global industry perspective, comprehensive analysis and forecast, 2017 - 2024", available at: www.zionmarketresearch.com/ report/cosmetic-products-market (accessed 15 November 2019).

\section{Corresponding author}

Riane Cherylise Dalziel can be contacted at:Riane.Dalziel@nwu.ac.za

For instructions on how to order reprints of this article, please visit our website: 